\title{
INHERITING WAR IN THUCYDIDES*
}

Abstract: This article argues that Thucydides represents the story of the Eurypontid Spartan kings, Archidamus and Agis, as a coherent, meaningful narrative spanning his text. Early on, Archidamus worries that his generation might leave war to their children as a kind of inheritance. His son Agis then does inherit the war, more literally than any other figure. The consequences of this malign bequest become clear as Agis comes to violate the traditional value system represented by his father. Formal naming of both men throughout their stories encourages the reader to view their appearances not as a series of isolated events but as a single narrative depicting the corruption of their family.

Keywords: Eurypontids, Peloponnesian War, inheritance, character, Thucydidean ethics.

$\mathrm{T}$

hucydides characterizes the Peloponnesian War as marked by a failure of the leadership of the great cities of Greece, as well as of ordinary citizens' capacities to judge and accept sage advice, disfunctions that are apparent in a number of passages the historian presents in his own voice. None of Pericles' successors, Thucydides says, stood out as the great general did, and in their lust for power, those who followed him sought to please the demos above all (2.65.10), a deterioration illustrated in the text by the progression from Pericles to Alcibiades or even Nicias. In the same passage, the historian seems to blame the mistaken judgment of both the demos and Athens' military leadership for the disastrous Sicilian Expedition, the former for misguidedly dispatching the Expedition in the first place, the latter for blundering in what should have been a salvageable enterprise (2.65.11). It has even been argued that Thucydides misinterprets or stretches historical reality to foster the impression of a dramatic decline in the quality of Athenian politicians after Pericles. ${ }^{1}$ The breakdown of good sense the historian sees in both leaders and followers is also clear in his stasis passage. A considerable part of his lengthy catalogue of the "changed meaning of words" (3.82.4) that corrodes society in wartime is dedicated to a distortion in the

\footnotetext{
* I would like to thank Antony Augoustakis and the anonymous $C J$ readers for their helpful comments. I am also grateful to J. E. Lendon and A. J. Woodman.

${ }^{1}$ Hornblower (1991) 340, 346-7.
}

THE CLASSICAL JOURNAL 116.3 (2021) 284-305 
capacity to assess the advice offered by a city's leaders, and a corresponding perversion in the types of proposals that are applauded or denigrated. This again seems to be borne out in the text, as the counsel offered by Spartan leadership does indeed change over the course of the History, ${ }^{2}$ while Book Eight is the culmination of dishonesty, "the most intrigue-filled book in the history," in which "doubledealing is a sport played by all sides." ${ }^{3}$

In contrast with his explicit assessment of the decline in Athenian leadership, Thucydides does not comment in his own voice on any parallel transformation in Sparta. But this paper argues that his narrative choices press the reader to note a decline similar to the one he claims Athens experienced. While the story of Athens depicts a series of ever weaker or less patriotic politicians, the transformation of Spartan leadership is most evident in the story of a single Spartan family. Thucydides demonstrates special interest in the Eurypontid kings, Archidamus (in power ca. 469-427 BCE) and his son Agis (ca. 427-401 BCE), each of whom features in multiple episodes. Early on, Archidamus presciently admonishes the Spartans that they might leave the war to their children as a kind of blighting

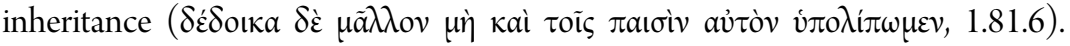
Archidamus' own son and heir is the individual this warning most obviously encourages the reader to consider: as Pericles' Funeral Oration advises, Archidamus brings the concerns of a father to the deliberations (2.44.3). Indeed, out of all the Spartans, Archidamus' son Agis bears the greatest burden of the patrimony of war, at least as Thucydides shapes his story, as his leadership comes to demonstrate many of its negative influences.

Throughout his story, and not just in his concern for the world that the next generation would inherit, Archidamus is a figure who thinks about generational roles to a greater degree than almost anyone else in the History. While the primary subject of his first speech is caution about embarking on a war, it is also to a large extent a meditation on age-groups, with the king emphatically aligning himself with the older one. His first words and initial self-representation in the text emphasize his age and the fact that he engaged in many past wars ( $\pi 0 \lambda \lambda \tilde{\omega} v \tilde{\eta} \delta \mathcal{E}$ $\pi \circ \lambda \varepsilon \mu \omega v, 1.80 .1$ ). So strong is his association with the past and its old-fashioned sensibilities that the character of Archidamus can be seen to owe much to Thucydides' own forerunner, Herodotus, in his presentation of Artabanus. ${ }^{4}$ The

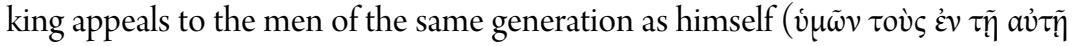

${ }^{2}$ Debnar (2001).

${ }^{3}$ Cartledge and Debnar (2006) 575.

${ }^{4}$ Pelling (1991). 
$\dot{\eta} \lambda ı \kappa i a x ~ o ́ \rho \tilde{\omega}, 1.80 .1)$ and advocates adhering to the ways of those who went before

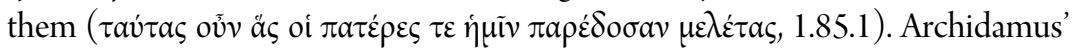
counterpart Pericles, by contrast, betrays little anxiety about future generations' wellbeing or even his city's continuing power. In the corresponding speech to Archidamus', he focuses primarily on the memory that his own and previous generations will leave to future Athenians and displays little concern for the life they will inherit: the memory of Athens' achievements will last forever, even if the

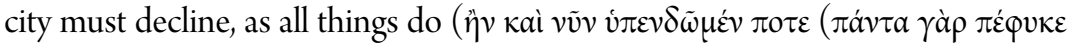
кaì ह̇ं $\alpha \sigma \sigma o \tilde{v} \sigma \theta \alpha \iota), 2.64 .3)$.

A failure to live up to the example set by one's father is a well-attested anxiety in ancient literature as early as Homer (e.g. Il. 5.800-1), and Herodotus, too, raises this theme repeatedly. The young Cambyses resembles his precocious and ambitious father Cyrus in childhood (3.3, cf. 1.114-15), only to fall dramatically short of his example in a maddened frenzy of impiety and violence (3.3-38), while Xerxes' anxiety to live up to his ancestors' example (7.8) lies behind his disastrous and impious attack on Greece. Thucydides is also interested in the generational aspects of personalities and leadership elsewhere, for example in his representation of the youthful and reckless Alcibiades and the wiser but hesitant Nicias (6.17-18).

Thucydides' construction of the stories of Spartan father and son shows the same type of pattern of generational decline as Homer and Herodotus illustrate: a single family succumbs to the corrosive forces of a violent era and produces a son who proves inadequate compared with his father on any number of criteria. I argue here that Thucydides uses both narrative elements and verbal cues to knit the stories of Archidamus and his son together to highlight the malign influence of Agis' inheritance, as well as creating an implicit comparison of this deteriorating family to proud Spartan stereotypes. The trajectory of the story shows the younger man's leadership and personality being warped in war, as he comes to brazenly exhibit failures of character once only hinted at in his father's characterization, and openly adopt other types of lawlessness. The story of these two men, read as a whole, thus demonstrates a Spartan version of the same decline - within a family and indeed a single individual — that Thucydides explicitly attributes to Athens' politicians.

The argument that follows assumes that Thucydides' construction of his History is highly intentional, and in particular that he deliberately chose which episodes to include and which to exclude, whom to name and how to name them, and that he shaped his representation of individual figures through both his presentation of speeches - which are likely to be at least to some degree his own 
inventions - and his selection of events. As only one example, it has long been noted that king Archidamus vanishes from Thucydides' text some time before the likely date of his historical death, which goes unmentioned. ${ }^{5}$ It has similarly been observed that Thucydides' representation of Agis seems more hostile than historical facts would at face value support. ${ }^{6}$ Choices of this sort and other storytelling elements allow an historian to endow a text with interpretative significance larger than the mere reporting of facts, but without calling into question the basic accuracy of the narrative, and thus merit our attention.

\section{The Characterization of Archidamus}

Thucydides is notably interested in the stories of the Eurypontid kings, much more so than their colleagues and regents; for example, despite Pleistoanax's intriguing story, Thucydides does not recount his experiences, actions or speeches at any length, once calling him simply "the other king" alongside Agis

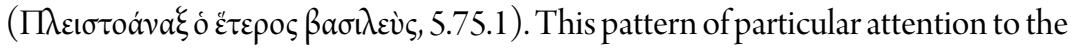
Eurypontids begins with an emphatic representation of Archidamus as a "traditional" Spartan. ${ }^{7}$ Upon the first introduction of Archidamus, the historian reports that the Spartans regarded him as "a man both intelligent and sophron"

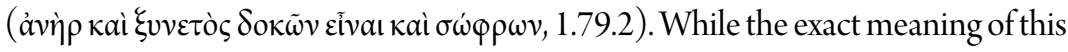
statement is debated, ${ }^{8}$ there is little doubt the king is associated with at least the appearance of old-fashioned restraint and carefulness in the History. The Spartans' assessment of their old king evolves into criticism under the pressures of war, ${ }^{9}$ but Thucydides offers no indication that Archidamus does not have his city's

${ }^{5}$ Hornblower (1991) 381.

${ }^{6}$ Powell (2017) 41-4 notes that the anecdotes about Agis were probably provided to Thucydides by biased Spartans, and the unflattering story that they paint must be understood in that context: "Elemente in der Erzählung des Thukydides suggerieren eine negative Tendenz seiner Quellen" (at 42).

${ }^{7}$ For the characterization of Archidamus as a traditionally pious and hesitant Spartan, see Wassermann (1953); Edmunds (1975) 90; Bloedow (1981) 135 and (1987) 64; Crane (1998) 212; Debnar (2001) 66-9.

${ }^{8}$ Badian (1993) $230 \mathrm{n} .40$ observes that Archidamus "is the only individual in Thucydides who is described as $\sigma \omega \dot{\varphi} \varphi \omega v$," although he argues that Thucydides' characterization of the king suggests he is "a pure Realpolitiker, devaluing sworn oaths to mere customary practice" (143), in contrast with what will be argued here. See Bloedow (1983) on the statement regarding Archidamus as sophron in both Thucydides' text and historical reality.

${ }^{9}$ Later on, nearly identical wording describes their rejection of precisely the same traits as treasonous ( $\delta$ oк $\tilde{\omega} v$-construction in both assessments of the king seems to call attention to the changing words used to judge him: just as Thucydides' says in his stasis passage, words change (3.82.3), and wisdom, 
best interests at heart. ${ }^{10}$ The text in fact goes on to associate Archidamus with euboulia, demonstrating his repeated attempts to use good sense to overcome raw emotion ${ }^{11}$ and thus suggesting that the Spartans' earlier, favorable, judgement of their king was more clear-headed. As many scholars have observed, his initial moralizing speech exhibits and defends many traditional Spartan virtues. ${ }^{12}$ Like Spartans typically, according to Thucydides (1.118.2, cf. 5.75.3), Archidamus is slow and reluctant to go to war, and his first major speech advocates against a war that is, at least for the moment, one of choice. He urges deliberate preparation rather than haste $(1.82 .1,4,5)$, advocates for time to consider the issues (1.85.1)

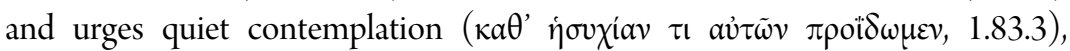
encouraging the Spartans not to be ashamed of "slowness and deliberation" (tò $\beta \rho \alpha \delta \dot{v}$ kaì $\mu \hat{\varepsilon} \lambda \lambda o v, 1.84 .1){ }^{13}$ This brand of thoughtful hesitation is among the traits that Thucydides later says the war eliminates ( $\mu \dot{\varepsilon} \lambda \lambda \eta \sigma \varsigma \varsigma \delta \dot{\varepsilon} \pi \rho \circ \mu \eta \theta \dot{\eta} \varsigma, 3.82 .4$ ), and will contrast with the eventual growing recklessness of his son's leadership. Archidamus also extols the virtues of a Spartan upbringing (1.84.4), and

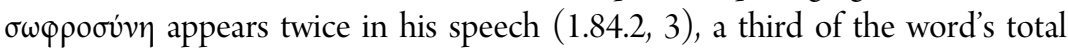
number of appearances in Thucydides. ${ }^{14}$ After losing this debate, the king is obedient to his city, subordinating his own wishes and dutifully leading the army into war, albeit proceeding at a characteristically slow pace (2.18.2).

Archidamus' pious behavior - or at least his concern not to appear impious also marks him as a typical representative of his state. ${ }^{15}$ Spartans are presented in historical sources as more careful about religious matters in warfare than citizens of other cities, ${ }^{16}$ and are shown honoring the divine in ways other states are not said

\footnotetext{
the sophia associated with Sparta and especially Archidamus, comes to be seen as a front for

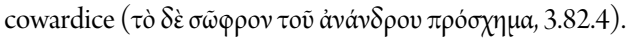

${ }^{10}$ While the Spartans may not appreciate his advice, he is correct in much of his assessment of the coming war; see e.g. Luginbill (1999) 204-6.

${ }^{11}$ Pelling (1991) 130.

${ }^{12}$ For Pericles and Archidamus as archetypes for their cities, see Pouncey (1980) 19, 40. Wassermann (1953) discusses Archidamus' traditional Spartan character, Debnar (2001) 66-9 Archidamus' praise for the traditional Spartan lifestyle. On the appealing nature of Archidamus' speech, especially in comparison with Sthenelaidas' brutal answer, see Bloedow (1981).

${ }^{13}$ On Spartan character as revealed by this statement, see Luginbill (1999) 84.

${ }^{14}$ The others are 1.32.4, 1.68.1, 3.37.3 and 8.64.5. Humble (2002) 86 discusses the often-noted association between the Spartans, and especially Archidamus, and sophrosyne.

${ }^{15}$ E.g. Hdt. 5.63.1-2, 6.56, 9.61.3-62.1; Pl. Alc. II 148d-9c. Modern discussions of Spartan religiosity include Popp (1957) 41-58; Michell (1964) 107; Parker (2002) 161-73; and Flower (2009).

${ }^{16}$ Goodman and Holladay (1986) 152-60.
} 
to do. ${ }^{17}$ This pattern holds in Thucydides as well, for example in the interest he attributes to the Spartans in keeping holidays (e.g. 5.75.2) and their repeated consultations of Delphi $(1.118 .3,3.92 .5){ }^{18}$ The Corinthians assume that their Spartan audience cares about such matters when they argue that the Peloponnesians have a divine sanction to go to war (1.71.5, 123.1-2); Spartans ascribe an earthquake to the fact that they once murdered helot suppliants (1.128.1); and they blame their bad luck in the first half of the war on their own side's wrongdoing (7.18.2). Thucydides, like his contemporaries, thus seems to represent Sparta in general as a notably religious city. But piety, like the ability to give and accept good judgement, is a characteristic that Thucydides reports does not survive long in the war $(3.82 .6,7,8)$, as becomes clear when the story of the Spartan royal family reaches its second wartime generation.

In keeping with his status as a conspicuous representative of his city's traditional ethos, Archidamus is the figure who seems most concerned with the piety, or at least with maintaining a reputation for piety, in Thucydides. This is especially evident in one of his most important appearances, in the Plataea narrative. As the Spartans prepare to attack the small city, the Plataeans deliver a speech that almost entirely ignores the current political crisis in favor of the sacred legacy of the Battle of Plataea, culminating in a direct appeal to the gods who witnessed oaths before the Persian War battle, namely the divinities of their own land and the ancestral gods of Sparta (2.71.4). In the midst of this prayer, Archidamus abruptly interrupts

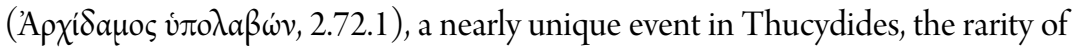
interruption suggesting a sincere emotional outburst. ${ }^{19}$ He then makes an unusually generous offer to allow the Plataeans to evacuate, pledging to support them anywhere they choose to go for the duration of the war. When the Plataeans decline this offer, the Spartan king makes a highly unusual statement ${ }^{20}$ directly to "however many gods and heroes possess this Plataean land" (2.74.2), a place "in which our fathers prayed to you and defeated the Medes, and you made it propitious for the Greeks to fight in" (2.74.2). He tells this audience that the Plataeans, not the Spartans, were the first to violate their oaths, reminds them that

\footnotetext{
${ }^{17}$ Richer (1999) and (2007) 242. Cf. Xen. Lac. 13.8, Plu. Arist. 17-18.

${ }^{18}$ Edmunds (1975) 89. Jordan (1986) 124-6, 136 discusses Spartan piety in Thucydides, and Pritchett I.122-3 shows that they allowed religion to interfere with military action more often than other states did.

${ }^{19}$ Only one other unexpected interruption occurs in Thucydides, a herald who has just stumbled upon the massacre of his countrymen (3.113.3). Debnar (2001) 96 attributes Archidamus' interruption to Spartan impatience with long-windedness.

${ }^{20}$ Rusten (1989) 217; Foster (2009) 370.
} 
he attempted in vain to offer a peaceful solution and asks them to take his side (2.74.2). Although scholars are divided on his sincerity, some taking his prayer to be all bluff ${ }^{1}$ and others seeing it as genuine, ${ }^{22}$ his apparently emotional interruption of the Plataean prayer and the unusual generosity of his previous offer to the Plataeans both point toward real trepidation about the implications of an attack on Plataea. Thucydides at least represents him as uniquely concerned about preserving a reputation for religiosity: the prayer, one of only a few in Thucydides and by far the longest, ${ }^{23}$ emphatically sets the king apart from every other figure in the History, ${ }^{24}$ and his son will seem to feel no compunction about maintaining appearances in this way.

Evidence on balance seems to suggest Archidamus' sincerity, but even taken this way, this story shows the king laying the foundation for future impieties. Thucydides may not have given us enough information for certainty about Archidamus "real" feelings, but from the perspective of the Plataeans — and, to a believer, that of the divinities receiving the prayer-Archidamus' actions, not his inner qualms, are surely the more salient question. There may be an attempt at mildness apparent in the fact that he besieges the city rather than attacking it directly as planned. ${ }^{25}$ But it is under Archidamus' leadership that the process begins which will lead to the utter destruction of the sacred city and its occupation by the hated Thebans. Whether against his will or not, he begins to pave the way for his son's less hesitant violation of norms.

Thucydides removes Archidamus from the text immediately after this apparent show of religious anxiety, despite the fact that his historical death seems to have taken place later ${ }^{26}$ This choice to terminate the king's textual existence early in the Historyimplies the disappearance of the impulse toward a more traditional ethos

\footnotetext{
${ }^{21}$ De Ste Croix (1972) 19-20 takes the Plataean appeal to the gods to be sincere, but not Archidamus'. Westlake (1968) 133 argues that although the narrative does not lay any damning or explicit responsibility at Archidamus' feet, it reveals that "his air of moderation and piety is sheer hypocrisy."

${ }^{22}$ HCT2.206 calls Archidamus' offer to allow the Plataeans to evacuate "generous ... for it would enable the Plataians to retire to Athens, to their wives and children and there fight." Bloedow (1983) 44 and Debnar (2001) 98 similarly treat the offer as in good faith. See also Zatta (2011) 327-30 for another argument that the offer represents a sincere attempt to avoid violence due to the cultural significance of Plataea.

${ }^{23}$ Brasidas also prays before attacking Acanthus (4.87.1-2), and the Athenians call on the divine after their speech at Sparta (1.78.4).

${ }^{24}$ Rusten (1989) 217 and Foster (2009) 370 discuss its unusual nature.

${ }^{25}$ Zatta (2011) 329 observes that Archidamus does not ravage the city as threatened but instead besieges it.

${ }^{26}$ Hornblower (1991) 381.
} 
that he represents, as well, helping to build a sense of change in the Spartan leadership. This is especially clear because Plataea, where Archidamus demonstrated some of his most important characteristics, is the scene of notable impiety in subsequent actions, seeming to represent a linear process of increasing brutality among the Spartans. In Book Three, Thucydides details a disturbing Spartan plan to besiege Plataea until its defenders reach a point of starvation that they surrender their city "willingly," so that it would not be subject to future truces requiring the return of conquered states (3.52.2). ${ }^{27}$ In order to facilitate this maneuver, the Spartans assure the fading Plataeans that surrender would result in only the guilty being punished, but thereafter propose to determine "guilt" based on the question of whether or not the Plataeans had performed service to Sparta in the current war ( $\dot{\varepsilon} \nu \tau \tilde{\omega} \pi 0 \lambda \dot{\varepsilon} \mu \omega \tau \tilde{\omega} \delta \varepsilon, 3.52 .4)$. Plataean supplicants beg their old Spartan allies for mercy, appealing again to piety $(3.58 .1,4,5 ; 59.4)$ as well as to the Spartans' longstanding reputation for virtue $(3.57 .1 ; 59.1)$. They express their

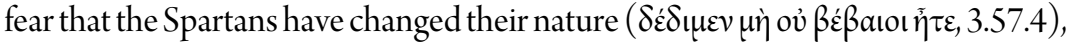
the very change that Thucydides seems to be studying in his representation of Spartan leadership. When the Peloponnesians nevertheless subject each Plataean individually to the cruel question before execution, without exception (á $\pi \dot{\alpha} \gamma o v \tau \varepsilon \varsigma$

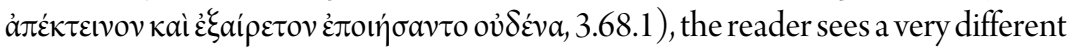
Sparta from the one represented in Archidamus' earlier interactions with the city.

\section{Archidamus' Introductions}

Throughout these passages, Thucydides offers almost continuous, full introductions of Archidamus, a pattern that will continue with his son Agis. These introductions typically include the king's patronymic and title, as well as often specifying that he was leading the action in question. The inherent emphasis on these kings' places in their family line in these introductions encourages the reader to adopt same perspective that Archidamus advocated in his early speeches, considering them not simply within the present moment but in a crossgenerational context extending from their ancestors into the future. The very repetition of the introductory formula for the Eurypontid kings, which finds no parallel in other family lines in Thucydides, also insists that father and son be considered in the context of one another, encouraging the reader to observe the effects of the legacy that Archidamus first worried Sparta might leave its children.

When he appears for the first time to speak against the war, Archidamus is, as

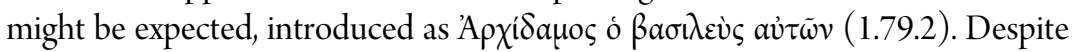

\footnotetext{
${ }^{27}$ Cartledge and Debnar (2006) 576 discuss Spartan cruelty at Plataea.
} 
the fact that his royal status has been noted in his first appearance, subsequent introductions of the king are even more formal. Archidamus is introduced again

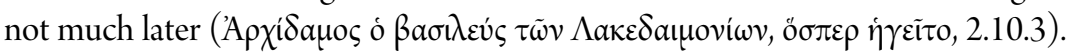
Just nine chapters later, he receives another full introduction, when he first invades

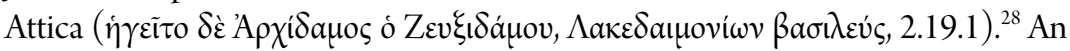
identically emphatic introduction again brings him to our attention at the opening

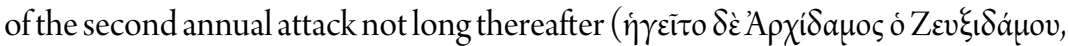

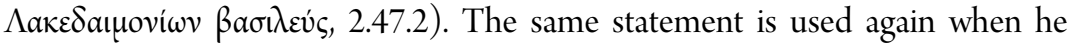

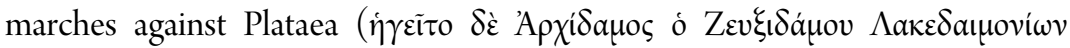
$\beta a \sigma \lambda \lambda \varepsilon v \varsigma, 2.71 .1)$. We are also reminded that he is the king only three sections later

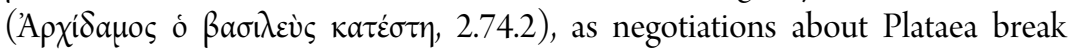
down. ${ }^{29}$ His final appearance is again fully introduced with an independent

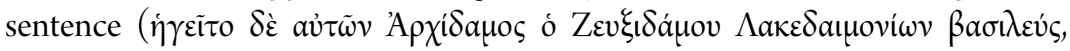
3.1.1)..$^{30}$

This treatment of the Eurypontid Spartan kings is noteworthy, because Thucydides typically does not use names as frequently as his contemporaries do. ${ }^{31}$ Of about 500 individual men mentioned in his work, 24 receive even one patronymic. $^{32}$ Even major figures are named rarely. Hornblower compares one of Archidamus' introductions with one of Pericles, ${ }^{33}$ and the reader might indeed expect the two men to be handled similarly, given their shared prominence in their

\footnotetext{
${ }^{28}$ HCT 2.69: "With the leader of the invading army given his most formal title, even though he has not only been formally introduced before as the army commander (10.3), but has by his personality and his policy been the central figure of the last chapter. With this last compare the more easily understandable formality of 1.139.5," for which read 1.139.4, an introduction of Pericles. Hornblower (1991) 272: "A formal introduction at this solemn moment for a man we have met several times already .... Th. held up his formal introduction until this 'point of no return." But the pattern of formal introduction did not begin at this point, but already at 2.10.3. Cartledge and Debnar (2006) 569 similarly argue that the formality at 2.19 is intended to emphasize the significance of the Spartan entry into Athenian territory.

${ }^{29}$ As Hornblower did with the instance at 2.19.1. Classen and Steup (1963) 2.194 explain this final case by pointing to the fact "dass hier entscheidende Tatsachen berichtet werden." But see below for the pervasiveness of the pattern, which holds whenever Archidamus appears, not just on the occasion of annual invasions.

${ }^{30}$ Hornblower (1991) 381 on 3.1.1: "Again ... a very formal, almost epic, introduction of a man we have already met several times. Th. does not intend us to forget the seriousness of these annual invasions." Classen and Steup (1963) 3.1 note that the phrasing recalls 2.47.2 and 4.2.1.

${ }^{31}$ Hornblower (2000) 134 observes that Thucydides uses names only about half as often as Herodotus does.

${ }^{32}$ Griffith (1961) 21-6.

${ }^{33}$ Hornblower (1991) 272.
} 
respective cities at the time of the outbreak of war. ${ }^{34}$ But while introductions awarded to Pericles occasionally contain "extra" information, they are far less formulaic than those of the Spartan kings. ${ }^{35}$ The name of Nicias, similarly, appears nearly 100 times and receives his patronymic in about an eighth of them. Pleistoanax, the other Spartan king, is fully named four times (1.114.1, 2.21.1, 5.16.1, 5.33.1), but despite deeming Pleistoanax, like Nicias, the most powerful

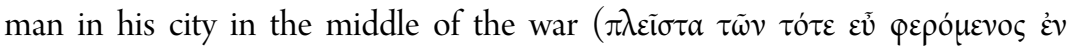

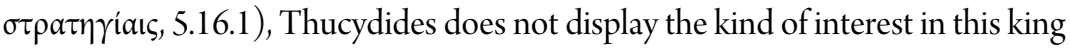
or his family that he does for Archidamus.

Thucydides' use of names seems to have several different purposes. Sometimes a full name can be seen to bolster the credibility of a report that might otherwise appear historically implausible. ${ }^{36}$ Other times characters receive such formalities to mark "special occasions," indicating the event in question is pivotal. Alcibiades, for example, is introduced with his patronymic four times, out of more than a hundred occurrences of his name ${ }^{37}$ and they occur only at key moments in his story, rather than marking his every appearance as the Eurypontids' introductions do. At least occasionally, Thucydides' employment of names serves literary ends. ${ }^{38}$

${ }^{34}$ Like Pericles, Archidamus presides over his state at what Thucydides, in the first sentence of his work, claims is its akme, and the historian treats the two men similarly, noting the exalted position each occupied in the eyes of his fellow-citizens (1.79.2, 1.139.2). On Pericles and Archidamus as archetypical members of their states, see Hussey (1985) 123-5.

${ }^{35}$ On his first appearance, Pericles is introduced by role and father's name (1.111.2), and several of his reappearances again occasion a patronym $(1.127 .1,2.34 .8)$. Thucydides' most elaborate introduction calls him "Pericles the son of Xanthippus, first of the Athenians at that time, most able both to speak and act" (1.139.4). His father's name and his leadership role are mentioned participially twice elsewhere $(2.13 .1,31.1)$, while his status as strategos is mentioned once alone in a genitive absolute (1.114.3). These introductions appear as a part of the syntax of a sentence focused primarily on other matters, rather than interrupting the flow of the narrative for a separate sentence, as the namings of Archidamus tend to do.

${ }^{36}$ Hornblower (1991) 443-4.

${ }^{37}$ His initial appearance in the text occasions editorial comment, in keeping with Thucydides'

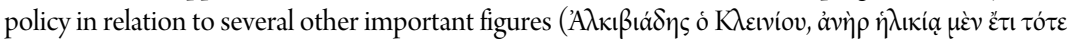

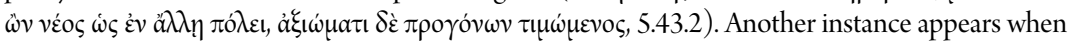

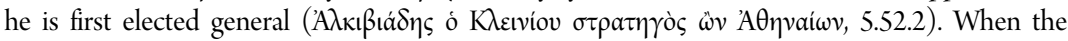
Athenians select leaders for the Sicilian Expedition, he, like the others, is named alongside his

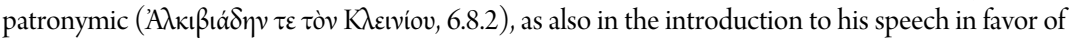

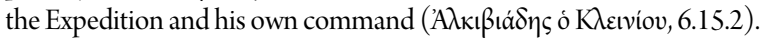

${ }^{38}$ Hornblower (2000) 134 argues that "Thucydides, unlike Homer, Herodotus, the tragedians, Pindar, and Plato, does not play games with names." Elsewhere, however, Hornblower also argues that Thucydides' omission of his own patronymic and substitution of his city at the opening of the text "conforms to literary tradition" (emphasis original) rather than standard historical practice 
"Euphemus," for example, has long been suspected of being a "speaking name,"39 and the unusual, and unusually full, names of the Plataean speakers in the Plataean Debate can also be read as significant. ${ }^{40}$

Sometimes Thucydides' pattern of introduction for the Spartan kings is thought to fall into the "special occasion" category, namely that every appearance of each of these men is marked as it is because it coincides with an especially pivotal historical moment. The occasion that is thought to earn these events their elevated status is usually the annual Peloponnesian invasions of Attica. ${ }^{41}$ And indeed, this strategy of invasion was of utmost emotional significance to the Athenians, even if was surprisingly ineffective militarily $(5.14 .3,7.28 .3)$. But the annual invasions do not fully explain Thucydides' pattern of introduction for the men. Three of Archidamus' introductions (2.19.1, 2.47.2 and 3.1) do indeed coincide with annual invasions of Attica. One additionally marks the attack on Plataea (2.72.1), which opens a new year of war even though it is not part of the strategy of annual attacks on Athens. The pattern of strikingly formal introductions, however, does not begin with the annual invasions but before them. ${ }^{42}$ Re-introduction within a narrative (e.g. 2.74.2) would also seem extraneous if the emphasis were on the importance of the action rather than the identity of the man leading it. Similarly, while one of Agis' introductions coincide with an annual invasion (4.2.1), most do not, while they do take precisely the same form. Both commentaries observe that one such case, an attack on Hysiae (5.83.2), is treated remarkable superficially by the historian; ${ }^{43}$ it was certainly a horrifying moment that tells us much about Agis, but it does not seem to be treated as a critical one in the war at large. The four annual invasions that are marked with this style of naming are thus part of a larger pattern, beginning before the annual invasions and continuing to appear after they are no longer a focus.

While Thucydides uses naming practices in diverse ways, including to emphasize the significance of an event, the central thread through his use of names in the story of the Eurypontids thus seems to be the identities of the Spartan kings

(Hornblower (1991) 4-5). Griffith (1961) 22 discusses Thucydides' literary usage of patronymics. On Thucydides' thoughtful distribution of names, see Shear (2011) 29.

${ }^{39}$ Orwin (1994) 131 n. 26.

${ }^{40}$ Bruzzone (2015).

${ }^{41}$ Hornblower (1991) 381 on 3.1.1. Cf. e.g. Classen and Steup (1963) 2.194, explaining the instance at 2.74 .2 as due to the fact "dass hier entscheidende Tatsachen berichtet werden."

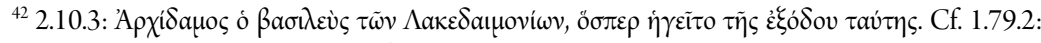

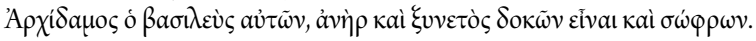

${ }^{43}$ HCT 4.153. Hornblower (2008) 213 endorses the view that this episode is related "with notable brevity and with no explanation." 
rather than any particular link between the events they appear in, or that these two men happen to appear exclusively in the context of especially seminal events while other figures, including other leaders, far more rarely or even never have a role in similarly consequential episodes. Thucydides does at times employ literary techniques involving names, as noted above, and one such technique that appears elsewhere is the use of full names to emphasize either continuity or a break with precedent, a literary flourish in which past and present are made to stand side by side, urging comparison in a way that might have had particular appeal to a historian. Homer, for example, has Nestor employ a patronym conveying a "history-generated image" of leadership and stability that encourages his audience to behave accordingly. ${ }^{44}$ Euripides in his Andromache accomplishes the opposite, using a patronym in the service of "measuring of the new generation by the standard of the old," resulting in an "ironic, even bitter, contrast." ${ }^{\text {"5 }}$ This second case appears to resemble Thucydides' use of the identities of the Spartan kings, as the younger man drifts painfully away from Spartan values.

\section{The Characterization and Introductions of Agis}

The reader is unlikely to forget the identity of a king of Sparta, or to lose track of his paternity. The historian thus seems to include otherwise superfluous information about Archidamus for literary ends rather than factual historical ones, constructing a sense of gravity around the man by repeatedly pausing the flow of the narrative to dwell on his identity. This seems a fittingly subtle Thucydidean touch to honor a leader whom most, although not all, readers find appealing. But this sense of solemnity becomes incongruous when it also introduces the next Eurypontid king, Agis. Rather than continuing to serve as a subtle but effective vehicle of gravitas, these introductions become bitterly out of place as the younger man progressively departs from the imagined traditional virtues of Sparta.

As scholars have noted, Thucydides' representation of Agis seems markedly, even unfairly dark in light of the available historical facts, which may be explained if Thucydides were forced to rely on sources hostile to the king. ${ }^{46}$ But this sinister coloring of Agis' story — and especially his apparently increasing impiety-is surprising, because Agis seems to have been generally popular. Xenophon reports that he was buried with utmost honors (Hel.3.3.1) and describes a pious man into the final events of his life $(H e l .3 .2 .24,26)$. Whether or not his sources were hostile,

\footnotetext{
${ }^{44}$ Brown (2006) 32.

${ }^{45}$ Phillippo (1995) 366. Stevens (1971) 90 also addresses this issue briefly.

${ }^{46}$ Powell (2017) 41-4.
} 
the darkness of Agis' story in Thucydides almost certainly owes something to the historian's own shaping of it. At the very least, Thucydides is selective about the contexts in which he represents the man: he is shown exclusively in active military conflict, either during or immediately before it or in its aftermath. Thucydides depicts at length Archidamus' struggles to convince his citizens of his beliefs about the nature and costs of warfare, while others, such as Alcibiades, continue to construct arguments about higher-level issues such as power and statehood throughout the war (e.g. 6.18). But he never depicts Agis engaging in direct speech, much less taking part in the kind of sophisticated deliberation that his father did. ${ }^{47}$ The narrative consequence of this authorial choice is to produce an image of a man whose life is reduced to the world of unreflective violence, perhaps showing the constriction of the sphere of Spartan kingship in the war. Even within this limited arena, his performance changes greatly over the course of his career, showing a conspicuous drift from traditional ideals.

Agis' kingship is roughly coterminous with the war, and he accordingly appears more often than his father did. Nonetheless, the same introductory patterns that were a striking part of his father's story are also woven into his kingship, spanning from Book Three to Book Eight. When the new king is first introduced, he is

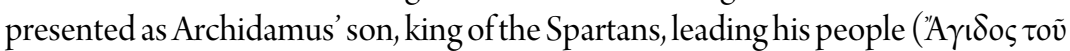

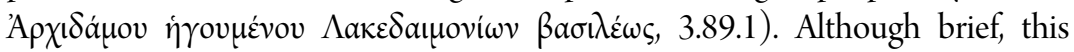
significant first encounter with Agis in the History suggests piety, as earthquakes cause him to withdraw an invasion of Attica. The same full-sentence formulation that appears repeatedly in Archidamus' story punctuates that of Agis as well, starting from his early appearances and continuing into Book Seven $(\dot{\eta} \gamma \varepsilon \tilde{\varepsilon} \tau o ~ \delta \grave{\varepsilon}$

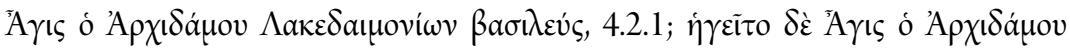

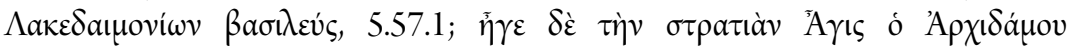

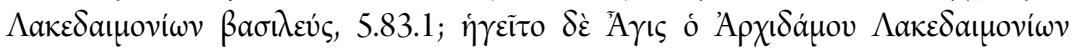
$\beta a \sigma \lambda \varepsilon v \dot{s}$, 7.19.1). He is introduced once as the king of the Spartans without his

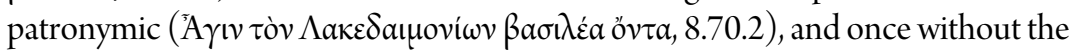

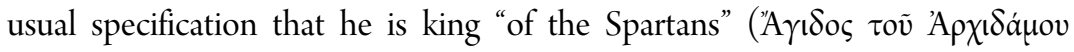
$\beta a \sigma \lambda \lambda \dot{\varepsilon} \omega \varsigma \dot{\eta} \gamma \gamma o v \mu \varepsilon \dot{\varepsilon} v v, 5.54 .1)$. As was the case for his father as well, the typical introductory statement is occasionally reinforced by repetition of some elements of his identity at key turning points within individual narratives ("A $ү ı \varsigma$ o $\beta a \sigma i \lambda \varepsilon v$ s, 4.6.1, following shortly after the full sentence at 4.2.1; 'A $\gamma ı \varsigma$ o $\beta a \sigma i \lambda \varepsilon v$ s, 5.71 .1 and

\footnotetext{
${ }^{47}$ Cartledge and Debnar (2006) 583 observe the difference between the thoughtful speeches of Archidamus and Agis' lack of language.
} 


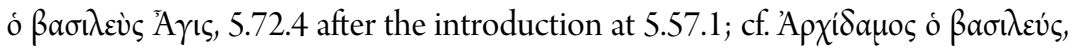
2.74.2).

These formalities seemed to serve as reminders of the at least ostensible solemnity of a king's presence in the story of Archidamus, but in that of Agis, they become ironic as Archidamus' fear of passing down a war to the younger generation is realized, and the corrosive significance of this inheritance becomes clear. After a brief invasion of Attica, shortened by a premature arrival that did not coincide with ripe grain (4.6), Spartans confront the Athenians on Pylos. Thucydides declines to mention Agis' role in the fiasco there, part of a pattern of obliqueness on the Spartan facet of this narrative. ${ }^{48}$ This means that Agis' first major appearance in the History is a vignette of the brutalizing education of a novice commander that appears as the Peloponnesian War enters its second phase. It begins with a nearly complete participial version of the introduction, as the troops march to Leuctra: "Agis the king, son of Archidamus, was leading"

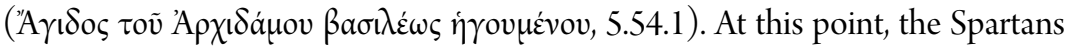
heed a negative sacrifice and turn back. In doing so, they exhibit a reverence consistent with the apparent significance of Archidamus' speech to the spirits of Plataea, ${ }^{49}$ with Agis' previous treatment of earthquakes (3.89.1), and with their city's established reputation. Thus far, then, Agis appears to be very much his father's son and fit the idealized image of a Spartan king.

Tensions increase, and the next year, shortly after the initial march to Leuctra in Thucydides' compressed narrative of this period, Agis again leads out his troops

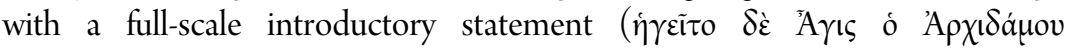
$\Lambda \alpha \kappa \varepsilon \delta a \iota \mu \nu v i \omega v \beta a \sigma \lambda \varepsilon v \dot{v} \varsigma, 5.57 .1)$, as part of a narrative in which he will again act in harmony with Spartan values. His troops are eager for battle, but Agis allows surrounded Argives to submit to arbitration (5.59.5). This is one of very few cases of apparent mercy in Thucydides, and is again in keeping with the behavior of other Spartan kings early on. The most obvious parallel in Thucydides is Archidamus' attempts to spare Plataea from attack (2.72-4), although Pleistoanax similarly marches into Attica and then retreats in the pre-war years $(1.114) .{ }^{50} \mathrm{But}$

\footnotetext{
${ }^{48}$ Strassler (1990).

${ }^{49}$ While it is impossible to know the real reason the Spartans turned back, the simplest explanation, advocated by Powell (2010) 129, is sincere religious feeling. Parker (1989) 158 takes the story in the same way. Whether or not the historical men turned back out of religious scruples, Thucydides' narrative gives us no reason to understand his text otherwise.

${ }^{50}$ Somewhat later on, we learn almost in passing that he is exiled for this action, as the Spartans conclude that he was bribed (2.21.1). It is impossible to know whether this bribe was really paid. Hornblower (1991) 186 and Powell (2010) 106 argue that the story is credible.
} 
when Agis makes much the same move in 418 BCE, the Spartans and their allies react to his moderation differently, with fury. Following this event and the loss of Orchomenos, they fly into a rage "in defiance of their normal character" (5.63.2), severely curtail the king's power and nearly confiscate his property, only refraining from doing so when he promises to atone for his "errors" (airias, 5.63.3) in the future (5.63.2-4).

Agis' subsequent actions break in increasingly dramatic fashion with traditional Spartan values. This is particularly clear because the historian features Agis almost exclusively in narratives that show him shedding such virtues. While other kings take part in other types of events, for example Pleistoanax negotiating the Peace of Nicias (5.16.1) and Archidamus counseling his citizens on the advisability of war, Thucydides notes Agis' presence from this point on exclusively to show him violating accepted behavior in matters of religion and the military. This is an especially poignant narrative choice, given that Spartan kings were charged with maintaining standards in these specific fields, ${ }^{51}$ and that the Spartans display particular anxiety about this kind of moral failure. ${ }^{52}$

Whereas his father advocated caution, Agis now becomes unrestrained. Receiving a call for assistance from Tegea, the Spartans march out to Mantinea with a huge army (5.64-5). Agis leads it so rashly that an older man warns him

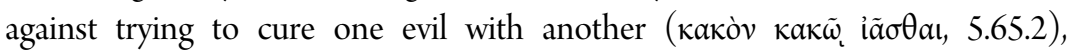
attempting to atone for his earlier caution by throwing care to the wind. The story of the Eurypontids continues to be interwoven with the idea of differing behavior between distinct generations: the wise man who calls out advice is $\tau \tilde{\omega} v$

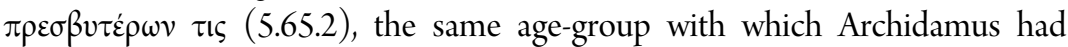
identified (oi $\pi \rho \varepsilon \sigma \beta \dot{v i \varepsilon} \rho \circ \mathrm{l}, 2.11 .1$ ), and the rarity of the word, which appears only once elsewhere in Book Two, encourages the reader to identify the two men as belonging to the same cohort. ${ }^{53}$ Just as he did with Archidamus, Thucydides again borrows from his own generational predecessor, Herodotus, to characterize the behavior of the older man ${ }^{54}$ who acts like a father-figure trying to pull Agis back from his newly adopted recklessness.

\footnotetext{
${ }^{51}$ Aristotle states that the powers of a Spartan king are limited to religious matters and waging external war (Pol. 1285a-b). Michell (1964) 105 discusses kings' power in the military. On the kings' otherwise relatively limited powers, see De Ste Croix (1972) 126.

${ }^{52}$ Moral failure, and specifically religious failure, was a particular fear of Sparta (Powell (2017) 39).

${ }^{53}$ The third is at 2.21.2.

${ }^{54}$ Powell (2017) 43 observes that the man's advice against "healing one evil with another" draws on Hdt. 3.53.4. Cf. Pelling (1991).
} 
Agis' apparent immaturity as a commander is also notable in his next appearance. The battle of Mantinea to a large degree focuses on Spartan institutions and leaders. ${ }^{55}$ Bichler notes that the narrative privileges the Spartan perspective, declining even to offer the names of the opposing army's leaders. Although his followers come off even worse than he does, the vision of Agis presented in this battle is negative, ${ }^{56}$ so much so that Powell argues that Thucydides' sources must have been hostile to Agis. ${ }^{57}$ The king nearly loses

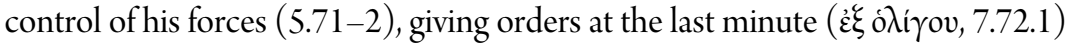
that are then ignored. Although the army's courage ultimately saves it, Thucydides

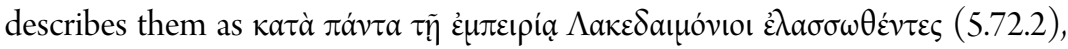
demonstrating an incompetence associated with inexperience, an assessment that cannot help but influence the reader's view of the novice king.

Agis continues to appear throughout the rest of the work, usually fully introduced, and the father-son comparison suggested by these introductions grows increasingly unflattering for the younger man. Thucydides reminds the

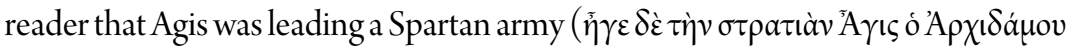

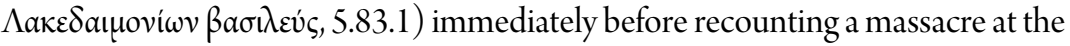
small city of Hysiae, a story that is all the more horrifying for its brevity and apparent pointlessness of the killings, indicated by the lack of explanation (5.83.2): "and taking all the free men they caught, they killed them and went away." ${ }^{58} H C T$ deems this attack "unfair and heartless" (4.153), and Hornblower an "atrocity." Hornblower also notes that the formal introduction that opens the episode does not appear to serve the same purpose it did before: at Mantinea, it seemed "intended to impart special solemnity," but at 5.83.1, introducing "a short nasty campaign," it seems to have a different function. ${ }^{59}$ Here, bitterly ironic, elevated language ushers in base behavior, while Thucydides' own lack of comment seems to suggest that such events are unremarkable at this stage in the war, and the narrative itself thus censors the king more effectively than any editorializing could have done.

In marked contrast with his father, or at least his father's self-representation, Agis also grows notably impious. While Archidamus displays trepidation about

\footnotetext{
${ }^{55}$ Rood (1998) 104-5: "Thucydides makes the battle [of Mantineia] a privileged locus for the evocation of their [the Spartans'] institutions."

${ }^{56} \operatorname{Bichler}(2009) 32$.

${ }^{57}$ Powell (2017).

${ }^{58}$ Lazenby (2004) 129 observes that this is not typical Spartan behavior and speculates that it might be vengeance for a pre-Peloponnesian War incident.

${ }^{59}$ Hornblower (2008) 150, misprinted as "84.1."
} 
ravaging Plataea, Agis occupies and fortifies another sacred city, Decelea, an episode in which he is again introduced in a separate full sentence $(\dot{\eta} \gamma \varepsilon \tilde{\varepsilon} \tau o \delta \dot{\varepsilon} \bar{A} \gamma\llcorner\varsigma$

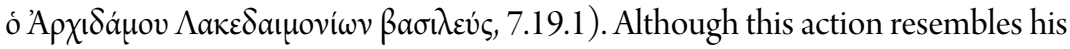
father's attack on Plataea, his attitude is different, as Agis, introduced once more a short time later, is enthusiastic in conducting the war from there ( $\beta a \sigma i \lambda \varepsilon \dot{\varepsilon} \omega \varsigma \tau \varepsilon$

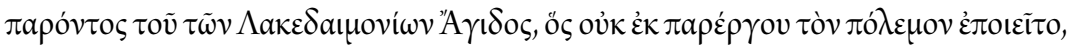
7.27.4). Thucydides reports that the action against Decelea, which had previously been treated as inviolable, allows Sparta extraordinary military advantages (7.27.4). The fact that this strategic move was not made earlier suggests the power of the taboo against such action, and inversely how shocking it is that Agis, whose foremost duties to his state include tending to its relationship with the gods, ${ }^{60}$ is willing to do so. This is especially so because these events represent a direct repudiation of his father's policy: Herodotus (9.73) states that the Spartans, due to their religious and social ties to Decelea, refused to violate the place both in mythological times and during the Peloponnesian War, at least up to the time of the publication of his work. ${ }^{61}$ Elsewhere as well, as Goodman and Holladay

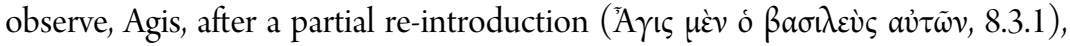
displays remarkable indifference to religion, offering to violate the peace of the Isthmian festival himself when the Corinthians prove unwilling to do so (8.9.1). The repugnance of this offer is particularly clear when the Corinthians reject it, a notable reversal from their earlier attempts to convince the Spartans to lay aside religious qualms and go to war (1.71.5). ${ }^{62}$

While Agis shakes off the obligations of one of his primary duties, religion, he seems to embrace the other, the military, ever more aggressively, and his increasingly despotic nature becomes particularly clear in Thucydides' unfinished final book. Agis' first appearance in Book Eight has him seizing money, plundering his opponents' property and taking hostages over the apparently vociferous

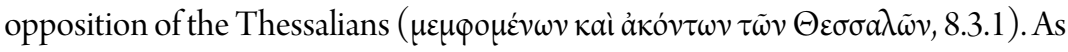
Thucydides does not normally record unanswered objections, his decision to note these complaints without offering any justification or excuse for Agis' behavior produces a narrative that reflects negatively on him.

\footnotetext{
${ }^{60}$ On Spartan kings as religious figures, see Parker (1989) 143,152-4.

${ }^{61}$ Hornblower (2008) 518: "there may have been a particular religious reason for their hesitation about Dekeleia" that led the Spartans to refrain from fortifying it for so long. See Salmon (1946) for this issue. On Spartan kings and religion, see Powell (2010).

${ }^{62}$ Goodman and Holladay (1986) 156 n. 30, 158, and Hornblower (2008) 781-2 note that Agis' indifference to this festival is a reversal of the normal pattern of Spartan piety.
} 
Thucydides' comments on Agis' relationship with his city, or lack thereof, similarly show him in a negative light and set up another contrast with his father. The alienation between the king and his state gradually increases, in parallel with the other changes in his character: in the early years of his kingship, Agis is desperate to remain in Sparta's good books. Although his recklessness at Mantinea abandons traditional Spartan caution, it also represents a frantic attempt to please his countrymen. Late in the war, however, this impulse seems to have vanished. Thucydides reports that Agis becomes markedly isolated from Sparta, acting

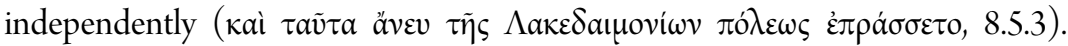
Indeed, much as Alcibiades abandons loyalty and peddles his talents wherever he can, Agis converts his forces into what is essentially a private army, which he is empowered to send wherever he pleases to raise men and money (8.5.3), more warlord than king. As his personal power increases and his connection with Sparta falters, his allies grow more obedient to him than his countrymen at home are, at

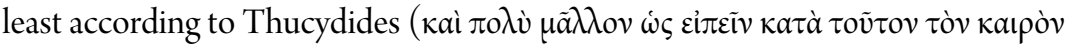

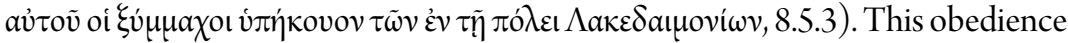
is not a manifestation of loyalty, but is rather due to the terror he inflicts on those

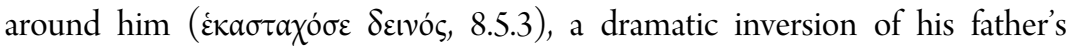
reluctant submission of his own will to the city's wishes when he first leads the Spartan army into Attica, as well as the Spartans' earlier tendency to listen to their allies while Athenians do not. ${ }^{63}$ As the war nears its conclusion, Thucydides thus shows Agis' evolution from an inexperienced but eager-to-please commander into the embodiment of the Spartan concern that a king not be allowed to become so powerful that he threatens the standing of his fellow-citizens. ${ }^{64}$ He ultimately comes to manifest the education inflicted by the "violent teacher, War" (3.82.2) that his cohort inherits from their fathers, and the consequences of these teachings for the leadership of the wartime generation.

\section{Implications of the Eurypontid Story}

The story of this Spartan family raises the question of whether the quality of the city's leadership changed for the worse in the course of the $5^{\text {th }}$ Century, or if the harder era simply pushed a similar man onto a different path. The latter seems

\footnotetext{
${ }^{63}$ Cartledge and Debnar (2006) 576 observe that earlier in the work, Spartans are shown to be more attentive to their compatriots and allies than Athenians are.

${ }^{64}$ Powell (2010) 89 and passim discusses the Spartans' anxiety that their king not threaten the standing of the homoioi, and that this fear significantly shapes Spartan discussions of their own past. "Much of 'Spartan history,' we must suspect, originated not as an abstract exercise in truth-telling but as a constitutional instrument."
} 
more likely to be the case. In an early discussion of attempts to control the direction of a war through strategy, Archidamus observes that human minds are

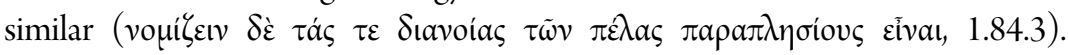
Thucydides elsewhere suggests that the opposite is also true: even as people attempt to shape war, war shapes them in uniform ways. As Archidamus does, Thucydides assumes that, despite cultural differences, people are essentially made in the same mold and respond to the stimulus of war similarly. He theorizes about war's capacity to warp individuals without apparent qualification as to their personal characteristics, making clear that polemosin its role as a biaios didaskalos inflicts a consistent set of moral, social and religious degradation on human beings

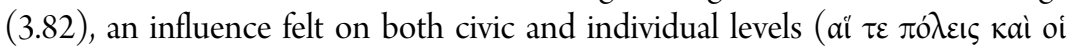
$i \delta i \tilde{\omega} \tau \alpha)$. The transformation of the Spartan royal family seems to reflect just these changes.

This understanding of war suggests that Agis responds to his circumstances much as anyone would. The same is true of his relatively admirable father. The formative years of Archidamus' rule predated the Peloponnesian War, before either the king himself or his fellow citizens with the power to punish him began learning the lessons of war. His son, on the other hand, had to prove himself and defend his fledgling rule during the grim realities of the Peloponnesian War. And he was, after all, a successful king, a man who adapted to his times, succeeded in war, and was loved by his people. The ethical facets of his adaptation to the new world, as detailed in Thucydides' text, thus seem to reveal as much about the time of his reign as they do about the man himself.

\section{Conclusions}

Archidamus seemed to possess a traditional "Spartan" character, apparent in his cautiousness, seeming piety, and dutiful leadership of the military. His son Agis, however, comes to ignore religion and to function as a vicious, isolated commander, indifferent to the concerns that were at the forefront of his father's mind, at least according to Thucydides' shaping of his life's story. The constricted scope of Agis' existence in Thucydides' text, in which he engages almost exclusively in transgressive violence and impieties, can be taken to demonstrate what it means to have one's adult life dominated by a war the previous generation chose. While some scholars have believed that the arguably unwarrantedly negative portrayal of Agis in the History is due to hostile sources consulted by the historian, it seems equally plausible that Thucydides constructs a narrative about the Eurypontid kings that reveals some of the ethical costs of war, as Archidamus himself foreshadows early on in the text. Thucydides' deliberate shaping of the narrative 
seems especially likely to be the key factor in this character study because in other sources, Agis is represented as successful, beloved and pious (Xen. Hel. 3.3.1; 3.2.24, 26).

Repeated elaborate introductory statements serve as a thread running through the Eurypontid story, promoting narrative continuity. The consistency of the introductory formula across the two wartime generations works together with the insistent reminders of lineage, inheritance and the past encapsulated within the formula to encourage the reader to view Agis' actions in the context of his family's history. The formal introduction that once seemed fittingly reverent for the father becomes jarringly out of place for the son, a reminder of how the family has changed. While the decline among Athenian politicians seems to be a misfortune, Thucydides' careful construction of the story of this individual Spartan family suggests that the war itself, in its capacity as a biaios didaskalos (3.82.2), degrades a good family and teaches a decent man to be an unscrupulous murderer.

Bilkent University, rachelbruzzone@gmail.com

RACHEL BRUZZONE

\section{WORKS CITED}

Badian, Ernst. 1993. From Plataea to Potidaea: Studies in the History and Historiography of the Pentecontaetia. Baltimore, MD.

Bichler, Reinhold. 2009. "Probleme und Grenzen der Rekonstruktion von Ereignissen am Beispiel antiker Schlachtbeschreibungen zur Fragestellung im Rahmen des Generelthemas der Tagung." In Das Ereignis: Geschichtsschreibung zwischen Vorfall und Befund, edited by Martin Fitzenreiter, pp. 17-34. London.

Bloedow, E. F. 1981. "The Speeches of Archidamus and Sthenelaidas at Sparta." Historia 30: 129-43.

__. 1983. "Archidamus the 'Intelligent' Spartan." Klio 65: 27-49.

_—. 1987. "Sthenelaidas the Persuasive Spartan." Hermes 115:60-6.

Brown, H. Paul. 2006. "Addressing Agamemnon: A Pilot Study of Politeness and Pragmatics in the Iliad" TAPA 136: 1-46.

Bruzzone, Rachel. 2015. "Killing the Past in Thucydides' Plataean Debate." CP110: 289300.

Cartledge, Paul and Paula Debnar. 2006. "Sparta and the Spartans in Thucydides." In Brill's Companion to Thucydides, edited by Antonios Rengakos and Antonis Tsakmakis, pp. 559-87. Leiden.

Classen, Johannes and Julius Steup, eds. 1862-1922. Thukydides. 8 vols. Berlin. Crane, Gregory. 1998. Thucydides and the Ancient Simplicity. Berkeley. 
Debnar, Paula. 2001. Speaking the Same Language: Speech and Audience in Thucydides' Spartan Debates. Ann Arbor, MI.

de Ste Croix, Geoffrey Ernest Maurice. 1972. The Origins of the Peloponnesian War. London.

Edmunds, Lowell. 1975. Chance and Intelligence in Thucydides. Cambridge.

Foster, Edith. 2009. "The Rhetoric of Materials: Thucydides and Lucretius." AJP 130: 367-99.

Flower, Michael A. 2009. "Spartan 'Religion' and Greek 'Religion.” In Sparta: Comparative Approaches, edited by Stephen Hodkinson, pp. 193-229. Swansea.

Goodman, Martin D. and A. J. Holladay. 1986. "Religious Scruples in Ancient Warfare." CQ36: 151-71.

Griffith, Guy Thompson. 1961. "Some Habits of Thucydides when Introducing Persons." PCPhS 187: 21-33.

Hornblower, Simon. 1987. Thucydides. Baltimore.

- - 1991-2008. A Commentary on Thucydides (3 vols.). Oxford.

_- 1992. "Thucydides' Use of Herodotus." In Philolakon: Lakonian Studies in Honour of Hector Catling, edited by Jan Motyka Sanders, pp. 141-54. London.

_ _. 2000. "Personal Names and Ancient Historians." In Greek Personal Names: Their Value as Evidence, edited by Simon Hornblower and Elaine Matthews, pp. 129-44. Oxford.

Humble, Noreen. 2002. "SOPHROSYNE Revisited: Was it Ever a Spartan Virtue?" In Sparta: Beyond the Mirage, edited by Anton Powell and Stephen Hodkinson, pp. 85109. Swansea.

Hussey, Edward. 1985. "Thucydidean History and Democritean Theory." In CRUX: Essays in Greek History Presented to G. E. M. de Ste Croix on his 75th Birthday, edited by Paul A. Cartledge and F. David Harvey, pp. 118-38. London.

Jordan, Boromir. 1986. "Religion in Thucydides." TAPA 116: 119-47.

Lazenby, John Francis. 2004. The Peloponnesian War: A Military Study. New York.

Luginbill, Robert D. 1999. Thucydides on War and National Character: Boulder, CO.

Michell, Humphrey. 1964. Sparta. Cambridge.

Orwin, Clifford. 1994. The Humanity of Thucydides. Princeton, NJ.

Parker, Robert. 1989. "Spartan Religion." In Classical Sparta: Techniques Behind her Success, edited by Anton Powell, pp. 142-72. London.

_—. 2002. "Religion in Public Life." In Sparta, edited by Michael Whitby, pp. 161-73. Edinburgh.

Pelling, Christopher. 1991. "Thucydides' Archidamus and Herodotus' Artabanus." In Georgica: Greek Studies in Honour of George Cawkwell, edited by Michael A. Flower and Mark Toher, pp. 120-42. London.

Phillippo, Susanna. 1995. "Family Ties: Significant Patronymics in Euripides' Andromache." CQ45: 355-71.

Popp, Harald. 1957. Die Einwirkung von Vorzeichen, Opfern und Festen auf die Kriegführung der Griechen im 5. und 4.Jahrhundert v. Chr. Würzburg, Germany. 
Pouncey, Peter R. 1980. The Necessities of War: A Study of Thucydides'Pessimism. New York.

Powell, Anton. 2010. "Divination, Royalty and Insecurity in Classical Sparta." In Sparta: The Body Politic, edited by Anton Powell and Stephen Hodkinson, pp. 85-136. Swansea.

—_ 2017. "Die Könige Spartas im Licht einer Krise und einer Aussergewöhnlichen Quelle." In Das antike Sparta, edited by Vassiliki Pothou and Anton Powell, pp. 37-55. Stuttgart.

Pritchett, William Kendrick. 1975-91. The Greek State at War (5 vols.). Berkeley.

Richer, Nicolas. 1999. "La Recherche des appuis surnaturels topiques par les Spartiates en guerre.” In Le Péloponnèse: Archéologie et histoire. Actes dela rencontre internationale del'Orient (12-15 mai 1998), edited by Josette Renard, pp. 135-48. Rennes.

Rood, T. 1998. Thucydides: Narrative and Explanation. Oxford.

Rusten, Jeffrey S., ed. 1989. Thucydides: The Peloponnesian War Book II. Cambridge.

Salmon, Edward Togo. 1946. "The Belated Spartan Occupation of Decelea: An Explanation." CR60: 13-14.

Shear, Julia. 2011. Polis and Revolution: Responding to Oligarchy in Classical Athens. Cambridge.

Stevens, Philip Theodore, ed. 1971. Euripides'Andromache. Oxford.

Strassler, Robert B. 1990. "The Opening of the Pylos Campaign." JHS 1 10: 110-25.

Wassermann, Felix M. 1953. "The Speeches of King Archidamus in Thucydides." CJ48: 193-200.

Westlake, Henry Dickinson. 1968. Individuals in Thucydides. London.

Zatta, Claudia. 2011. "Conflict, People, and City-Space: Some Exempla from Thucydides' History.” CA30: 318-50. 